\title{
Mechanism of Neuromuscular Dysfunction in Krabbe Disease
}

\author{
Ludovico Cantuti-Castelvetri, ${ }^{1}$ Erick Maravilla, ${ }^{1}$ Michael Marshall, ${ }^{1,4}$ Tammy Tamayo, ${ }^{2,4}$ Ludovic D'auria, ${ }^{1}$ \\ John Monge, ${ }^{2}$ James Jeffries, ${ }^{2}$ Tuba Sural-Fehr, ${ }^{1}$ Aurora Lopez-Rosas, ${ }^{1}$ Guannan Li, ${ }^{3,4}{ }^{\circ}$ Kelly Garcia, ${ }^{2}$ \\ Richard van Breemen, ${ }^{3,4}$ Charles Vite, ${ }^{5}$ Jesus Garcia, ${ }^{2}$ and Ernesto R. Bongarzone ${ }^{1}$ \\ Departments of ${ }^{1}$ Anatomy and Cell Biology, ${ }^{2}$ Physiology and Biophysics, and ${ }^{3}$ Medicinal Chemistry and Pharmacognosy and ${ }^{4}$ Medical Scientist Training \\ Program, University of Illinois at Chicago, Chicago, Illinois 60612, and ${ }^{5}$ School of Veterinary Medicine, University of Pennsylvania, Philadelphia 19104
}

The atrophy of skeletal muscles in patients with Krabbe disease is a major debilitating manifestation that worsens their quality of life and limits the clinical efficacy of current therapies. The pathogenic mechanism triggering muscle wasting is unknown. This study examined structural, functional, and metabolic changes conducive to muscle degeneration in Krabbe disease using the murine (twitcher mouse) and canine [globoid cell leukodystrophy (GLD) dog] models. Muscle degeneration, denervation, neuromuscular [neuromuscular junction (NMJ)] abnormalities, and axonal death were investigated using the reporter transgenic twitcher-Thy1.1-yellow fluorescent protein mouse. We found that mutant muscles had significant numbers of smaller-sized muscle fibers, without signs of regeneration. Muscle growth was slow and weak in twitcher mice, with decreased maximum force. The NMJ had significant levels of activated caspase-3 but limited denervation. Mutant NMJ showed reduced surface areas and lower volumes of presynaptic terminals, with depressed nerve control, increased miniature endplate potential (MEPP) amplitude, decreased MEPP frequency, and increased rise and decay rate constants. Twitcher and GLD dog muscles had significant capacity to store psychosine, the neurotoxin that accumulates in Krabbe disease. Mechanistically, muscle defects involved the inactivation of the Akt pathway and activation of the proteasome pathway. Our work indicates that muscular dysfunction in Krabbe disease is compounded by a pathogenic mechanism involving at least the failure of NMJ function, activation of proteosome degradation, and a reduction of the Akt pathway. Akt, which is key for muscle function, may constitute a novel target to complement in therapies for Krabbe disease.

Key words: Akt; Krabbe disease; neuromuscular junction; neuropathy; proteosome; psychosine

\section{Introduction}

Krabbe disease or globoid cell leukodystrophy (GLD) is an autosomal recessive disease caused by the deficiency of lysosomal $\beta$-galactosylceramidase (GALC) and the accumulation of psychosine (galactosyl-sphingosine), a potent lipid raft-associated neurotoxin (Krabbe, 1916; Suzuki, 2003; White et al., 2009). Psychosine is believed to trigger pathogenic mechanisms leading to myelin breakdown (Igisu and Suzuki, 1984; Takahashi and Suzuki, 1984; Taniike and Suzuki, 1994) and axonal dysfunction (Galbiati et al., 2007; Castelvetri et al., 2011; Smith et al., 2011; Cantuti-Castelvetri et al., 2012; Cantuti Castelvetri et al., 2013; Smith et al., 2014).

Typically, Krabbe patients are infants with a rapid and invariably fatal course. The signs of disease begin with hyperirritability,

Received June 14, 2014; revised 0ct. 26, 2014; accepted Nov. 26, 2014.

Author contributions: J.G. and E.R.B. designed research; L.C.-C., E.M., M.M., T.T., L.D., J.M., J.J., A.L.-R., G.L., K.G., T.S.-F., J.G., and E.R.B. performed research; K.G. and C.V. contributed unpublished reagents/analytic tools; L.C.-C., R.v.B., J.G., and E.R.B. analyzed data; L.C.-C., J.G., and E.R.B. wrote the paper.

This study was partially funded by a Chancellor Award (L.C.-C.), National Institutes of Health Grant RNS065808A, and a grant from the Legacy of Angels Foundation (E.R.B.).

Correspondence should be addressed to Dr. Ernesto R. Bongarzone, Department of Anatomy and Cell Biology, College of Medicine, University of Illinois at Chicago, 808 South Wood Street, MC512, Chicago, IL 60612. E-mail: ebongarz@uic.edu.

DOI:10.1523/JNEUROSCI.2431-14.2015

Copyright $\odot 2015$ the authors $\quad 0270-6474 / 15 / 351606-11 \$ 15.00 / 0$ hyperesthesia, and limb stiffness. Rapid and severe deterioration of motor and mental function ensues. In the final stage of disease, individuals are neurologically impaired and blind (Suzuki, 2003). Neuropathology is described as the extensive loss of oligodendrocytes and myelin, fibrillary astrogliosis, and infiltration of globoid cells or multinucleated macrophages (Wenger et al., 2000; Suzuki, 2003).

Current treatments relay on the amelioration of symptoms after hematopoietic replacement via transplantation of hematopoietic stem cells (Escolar et al., 2005) or bone marrow cells (Yagi et al., 2005; Krivit et al., 1998; Luzi et al., 2005; Galbiati et al., 2009; Reddy et al., 2011). However, although these therapies slow disease progression, neurological and motor symptoms continue to develop at a slower pace and ultimately lead to significant paralysis and death. Thus, improved therapies are needed.

The mechanism of Krabbe muscle dysfunction remains unclear. Patients show rapid myopathy (Dehkharghani et al., 1981; Marjanović et al., 1996), with reduced muscle growth and strength. Various factors may contribute to this myopathy, including demyelination, axonopathy, motor neuron disease, and intrinsic defects of muscle cells. Demyelination of peripheral nerves in the twitcher mouse, the natural murine model for this disease (Duchen et al., 1980), is evident by the week 3 of life (Powell et al., 1983; Tanaka et al., 1988). Concurrently, there are 
axonal defects (Castelvetri et al., 2011) caused by deregulation of protein phosphatases 1 and 2A (Cantuti-Castelvetri et al., 2012) and deficits of fast axonal transport brought on by deregulation of glycogen synthase kinase $3 \beta$ (GSK3 $\beta$ ) in mutant axons (Cantuti Castelvetri et al., 2013). These defects may act cooperatively to block nerve conduction (Toyoshima et al., 1986; Dolcetta et al., 2005), contributing to flaccid paralysis, and motor deficits.

Akt regulation of muscle mass has received increasing attention because of its role in healthy and diseased muscle (Dobrowolny et al., 2011; Bodine et al., 2001; Léger et al., 2006a,b). After innervation, myofibrils undergo extensive growth, which is attributed to protein synthesis and degradation. The Akt pathway plays a central regulatory role in this restructuring process (Gosmanov et al., 2004; McCurdy and Cartee, 2005), through the activities of FoxO transcription factors and other downstream pathways, such as GSK3 $\beta$. Potentially, abnormalities in the Akt pathway may also be contributing to neuromuscular dysfunction in Krabbe disease.

In this study, we have evaluated the structure and function of the neuromuscular junction (NMJ) and the status of the Akt pathway in twitcher muscles. Our studies show a complex pathogenic mechanism involving dysfunction and structural alterations of the NMJ, peripheral neuropathy, and reduction of the Akt pathway in mutant muscles. These findings suggest the development of intrinsic and extrinsic defects affecting muscle function in Krabbe disease.

\section{Materials and Methods}

Animals. Animal work was completed under protocols approved by the Institutional Animal Care and Use Committees at the University of Illinois at Chicago (mice) and the University of Pennsylvania (dogs). Both institutions are fully accredited by Association for Assessment and Accreditation of Laboratory Animal Care International and adhere to recommendations put forth by the National Institutes of Health Guide for the Care and Use of Laboratory Animals, Edition 8. twitcher heterozygous and twitcher-Thy1.1-yellow fluorescent protein (YFP) heterozygous expressing axonal YFP (twitcher-YFPax) mice were housed under standard housing conditions (Castelvetri et al., 2011). Homozygous twitcher and twitcher-YFPax mice were genotyped as described previously (Sakai et al., 1996; Feng et al., 2000). Both mouse lines were maintained in their original C57BL/6j genetic background. Mature animals from the GLD line were bred to produce dogs with autosomal recessive GLD disease. Peripheral blood leukocytes from all the dogs were tested at $1 \mathrm{~d}$ of age for the GLD missense mutation (A to C at cDNA position 473, Y158S), using a PCR-based DNA test. Dogs were classified as normal or affected if they had no copies of or were homozygous for the mutation. Heterozygous animals were not used. Three affected $(n=3$ male) and two normal ( $n=$ 2 females) dogs were evaluated. Dogs were 16-17 weeks of age at the time the animals were killed and tissue collection.

Processing of tissue for histology and immunohistochemistry. Animals were anesthetized and perfused with saline, followed by $4 \%$ paraformaldehyde/saline. Soleus or gastrocnemius muscles were soaked in sucrose and processed for cryosectioning. Diaphragms were used as wholemount preparations. Cryosections $(50 \mu \mathrm{m})$ were mounted onto slides and stained with hematoxylin-eosin or Gomori's trichrome. For analyses of NMJ innervation and axonal death, sections were dried for $15 \mathrm{~min}$ at $37^{\circ} \mathrm{C}$ and washed in PBS. Tissue was blocked/permeabilized in $4 \%$ $(\mathrm{w} / \mathrm{v}) \mathrm{BSA} / 0.1 \%(\mathrm{v} / \mathrm{v})$ Triton X-100/PBS for $2 \mathrm{~h}$ at room temperature and incubated with Alexa Fluor-555 or Alexa Fluor-488 $\alpha$-bungarotoxin (BTX; 1:500; (Invitrogen), antibody against the medium subunit of neurofilaments (NF-M; 1:1000; Millipore), or an antibody against activated caspase-3 (1:500; Millipore) in blocking solution for $48 \mathrm{~h}$. Slides were rinsed in PBS and incubated with fluorescent secondary antibodies for $1 \mathrm{~h}$ at room temperature, washed in PBS, and mounted with Vectashield
(Vector Laboratories). Confocal microscopy was performed using a confocal laser Meta Zeiss 710 scanning microscope. Light microscopy for fiber morphology and fibrosis analyses was completed using a Leica upright microscope.

Primary culture of skeletal muscle cells. Primary cultures of skeletal muscle tissue were prepared from muscle of newborn mice [at postnatal day $0(\mathrm{P} 0)]$ as described previously (Alden and García, 2001). Muscle was finely minced and incubated in $\mathrm{Ca}^{2+}, \mathrm{Mg}^{2+}$ free rodent Ringer's solution: $155 \mathrm{~mm} \mathrm{NaCl}, 5 \mathrm{~mm} \mathrm{KCl}, 11 \mathrm{~mm}$ glucose, and $10 \mathrm{~mm}$ HEPES, pH 7.4 containing collagenase type IA ( $1 \mathrm{mg} / \mathrm{ml}$; Sigma) at $37^{\circ} \mathrm{C}$ for $30-45 \mathrm{~min}$. Dissociated muscle was triturated with a Pasteur pipette in plating medium (v/v, 80\% DMEM with $4.5 \mathrm{~g} / \mathrm{l}$ glucose, $10 \%$ horse serum, and $10 \%$ calf serum). Large debris were removed from the solution by filtration and centrifugation, and a suspension of single cells was obtained. Cultures were maintained in a $37^{\circ} \mathrm{C}$ incubator with a gas mixture of $95 \%$ air and $5 \% \mathrm{CO}_{2}$. Fusion and differentiation into myotubes were promoted after $2 \mathrm{~d}$ in culture by reducing horse serum concentration to $5 \%$ and removing fetal calf serum. In some experiments, wild-type myotubes were incubated with $5 \mu \mathrm{M}$ psychosine for $1 \mathrm{~h}$.

Psychosine determination. Psychosine was measured after lipid extraction using tandem mass spectrometry as described previously (Galbiati et al., 2009).

NMJ morphometry. NMJs were imaged on longitudinal sections from gastrocnemius muscles collected from P30 twitcher-YFPax and wildtype YFPax age-matched controls. YFP-positive $\left(\mathrm{YFP}^{+}\right)$axonal endplates were imaged using a Zeiss 710 Laser Scanning Microscope, using a $63 \times / 1.4$ numerical aperture or $40 \times / 1.3$ numerical aperture oilimmersion objective. Sections were Z-scanned (thickness, $0.5 \mu \mathrm{m} / \mathrm{scan}$ ). Images were reconstructed using Zen 2011 LSM tiff stack generating software and the LSM tiff stack imported into MATLAB 8.1. A custom MATLAB analysis routine was used to generate triangular surface and tetrahedral volume reconstructions from uncompressed LSM tiff stacks (Nédélec et al., 2001). An image stack was first filtered with a custom deconvolution kernel (Campisi and Egiazarian, 2007). Next, the filtered images were cropped manually via binary masking. Processed image stacks were resampled and interpolated to generate cubic unit voxel axes of $3 \mathrm{D}$ space. Last, a tetrahedral space-filling model of the resampled image stack was generated from the resampled grayscale image stack (Fang and Boas, 2009). The volume was calculated by summing all volumes of tetrahedra in the space-filling model. The surface area was calculated by summing all surface areas of tetrahedra faces exposed at the surface of the space-filling model.

Measurement of twitch force. Mice were anesthetized with ketamine (100 mg/kg for wild-type mice and $75 \mathrm{mg} / \mathrm{kg}$ for twitcher mice) and xylazine $(5 \mathrm{mg} / \mathrm{kg}$ for both) given intraperitoneally and re-dosed as needed. The tibialis anterior (TA) muscle and the sciatic nerve were exposed. The distal tendon of the TA muscle was freed from its insertion and attached to a force transducer (AD Instruments) fixed to a 3D micromanipulator. The muscle, oriented normal to the transducer, was continuously rinsed with warmed saline bubbled with $95 \% \mathrm{O}_{2}$ and $5 \% \mathrm{CO}_{2}$. Body temperature was maintained by placing a heating pad under the animal. TA muscles were stimulated via the isolated deep fibular nerve with a pulse stimulator (model 2100; A-M Systems). After the optimal voltage and muscle length were determined, the nerve was stimulated 10 times every $3 \mathrm{~s}$ with $1 \mathrm{~ms}$ pulses. The amplitude in each twitch was measured and averaged for each fiber. The maximal force of twitching (in grams) was calculated for six mice in each group.

Electrophysiological recording of neuromuscular transmission. The neuromuscular preparation for electrophysiological recording of postsynaptic events was as described previously (Chen et al., 2004) with some modifications. Wild-type and twitcher animals were deeply anesthetized with isoflurane and killed. The extensor digitorum longus muscle was dissected and mounted such that nerves running through the fingers were visualized. The experimental chamber contained normal Ringer-Krebs solution: $145 \mathrm{~mm} \mathrm{NaCl}, 5 \mathrm{~mm} \mathrm{KCl}, 2.5 \mathrm{~mm} \mathrm{CaCl}_{2}, 1 \mathrm{~mm}$ $\mathrm{MgSO}_{4}, 10 \mathrm{~mm} \mathrm{Na}$-HEPES, $10 \mathrm{~mm}$ glucose, and $1 \mathrm{mg} / \mathrm{ml}$ neostigmine, pH 7.4 adjusted with $\mathrm{NaOH} / \mathrm{HEPES}$. Intracellular microelectrodes filled with $3 \mathrm{M} \mathrm{KCl}$ had a resistance of 20-40 M . Muscle fibers were 
inserted near the NMJ to minimize attenuation of the signals. Spontaneous miniature endplate potentials (MEPPs) were measured from a membrane potential of $-75 \mathrm{mV}$ with an Axoclamp-2A amplifier (Molecular Devices) and stored for subsequent analysis. MEPPs were recorded at room temperature, $22-24^{\circ} \mathrm{C}$. Event frequencies, amplitudes, and time constants of rise and decay were averaged for each muscle fiber examined. Events from a minimum of six mice per group were examined.

Gene expression analysis. RNA from acutely isolated soleus muscle was purified with the TRIzol reagent (Invitrogen) and retrotranscribed using the Superscript III kit (Invitrogen) according to the instructions of the manufacturer. Quantitative real-time PCR analyses were performed with primers specific for the following genes: acetylcholine receptor $(\mathrm{AChR})-\beta$, forward, $5^{\prime}$-ACCACGACGCA CTGAAGG and reverse, $5^{\prime}$-GGTCCCGACGC TTGTGA; AChR- $\gamma$, forward, $5^{\prime}$-AGAACAAT GTGGACGGTGTC and reverse, 5' -GCAGCC AGTAGATACACCG; atrogin-1, forward, 5ATGAAGATGCCACACAAT and reverse, 5CATGAAACACAGACATTGCC; and 60S acidic ribosomal protein $\mathrm{P} 0$, forward, $5^{\prime}$-TC GCTTTCTGGAGGGTGTC and reverse, $5^{\prime}$-CA CAGACAATGCCAGGACG. Primers were tested on a standard curve, and the efficiency and the correlation coefficient were higher than $90 \%$ and 0.990 , respectively. PCR analysis was calculated with the $\Delta \Delta \mathrm{Ct}$ method (Livak and Schmittgen, 2001).

Immunoblotting. Tissues were homogenized in lysis buffer [ $1 \mathrm{~mm}$ PMSF, 2 mм sodium orthovanadate, $1 \mathrm{~mm} \mathrm{NaF}, 20 \mathrm{~mm}$ Tris $\mathrm{HCl}, \mathrm{pH}$ 7.4, $1 \%(\mathrm{v} / \mathrm{v})$ Triton X-100, $150 \mathrm{~mm} \mathrm{NaCl}, 5$ $\mathrm{mm} \mathrm{MgCl}_{2}$, and $300 \mathrm{~nm}$ okadaic acid]. Samples were sonicated briefly on ice and collected by centrifugation for $5 \mathrm{~min}$ at $5000 \mathrm{rpm}$. Protein was quantified with the Bradford assay (Bio$\mathrm{Rad})$, and equal amounts of protein $(10 \mu \mathrm{g})$ were loaded on $4-12 \%$ Bis-Tris gels (Invitrogen). The protein was transferred onto polyvinylidene fluoride membranes (Bio-Rad). Blots were blocked in 5\% milk, $1 \%$ BSA, and $0.05 \%$ Tween 20 in TBS (blocking solution) and incubated with primary antibodies at $4^{\circ} \mathrm{C}$ overnight. Secondary peroxidase-conjugated antibodies were incubated at room temperature for $1 \mathrm{~h}$. The following primary antibodies were used: monoclonal mouse anti-GAPDH (1:3000; Sigma), polyclonal rabbit antiphosphorylated GSK3 $\beta$ (Ser9; 1:5000; Cell Signaling Technology), polyclonal rabbit anti-GSK3 $\beta$ (1:5000; Cell Signaling Technology), polyclonal rabbit antiphosphorylated Akt (1:5000; Ser473; Cell Signaling Technology), polyclonal rabbit anti-Akt (1:5000; Cell Signaling Technology), polyclonal rabbit anti-ubiquitin (1:100; Santa Cruz Biotechnology), polyclonal rabbit antiphosphorylated eIF4E binding protein 1 (4EBP1; 1:2000; Cell Signaling Technology), and polyclonal rabbit anti-4EBP1 (1:2000; Cell Signaling Technology). Membranes were developed using the Enhanced Luminescence kit (Thermo Fisher Scientific). Bands were semiquantified (NIH Image J), and relative abundance of a particular protein was normalized to GAPDH.

Statistical analysis. Results are expressed as mean \pm SE. Sample size ranged from three to six, depending on the experiment. Data were analyzed using two-tailed unpaired $t$ test ( $95 \%$ confidence interval) or by
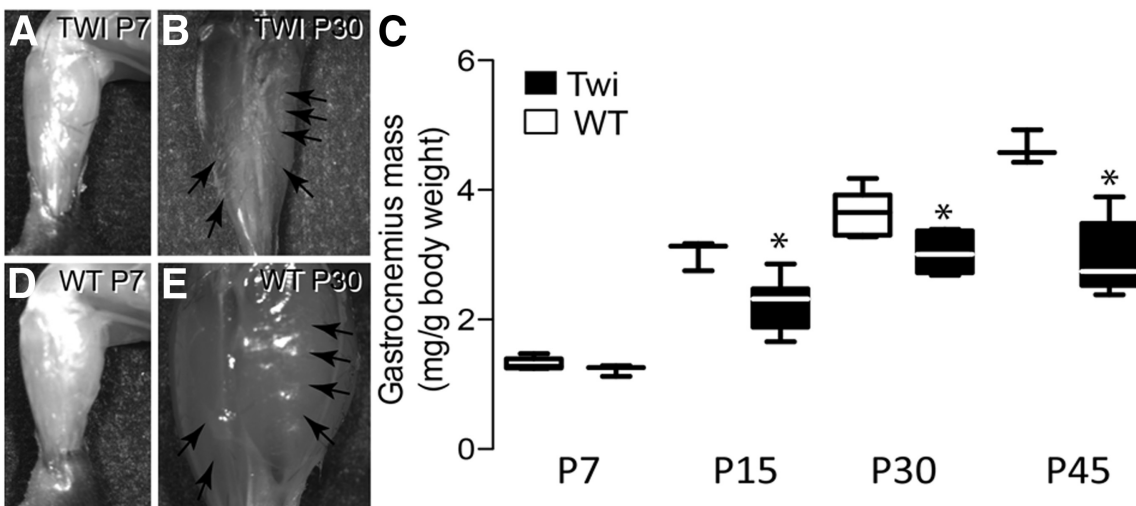

Figure 1. Muscle atrophy in the twitcher mouse. $A, B, D, E$, Representative pictures of the right leg of $P 30$ twitcher (Twi, $A, B$ ) and wild-type (WT, $D, E$ ) mice. A reduction in mass is visible in twitcher muscles (arrows). $C$, The weight of the twitcher gastroc
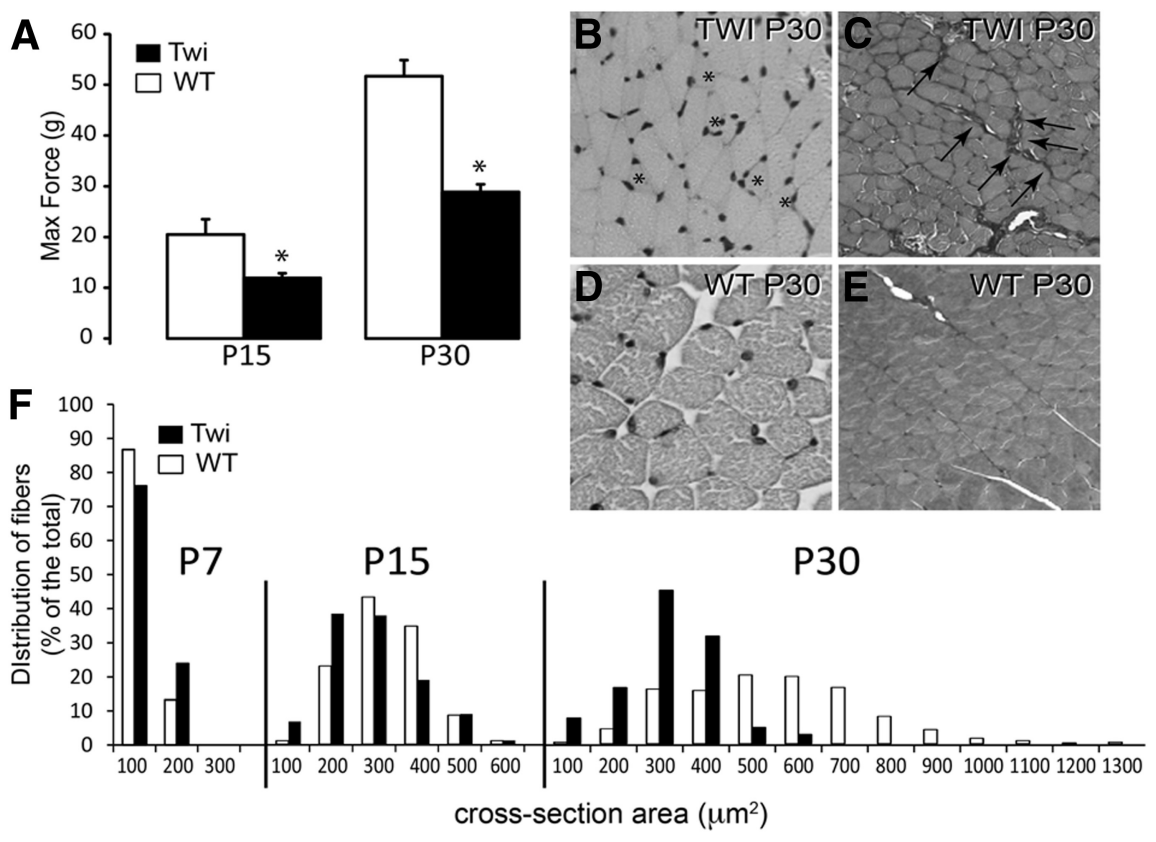

Figure 2. Decreased isometric force, fibrosis, and decreased fiber size in twitcher mice. $A$, Measurement of isometric twitching force was done on TA muscles of twitcher (Twi) and wild-type (WT) mice at P15 and P30. Force (in grams) was normalized against histologically visible after Gomori's trichrome staining of coronal sections of gastrocnemius muscles. $\boldsymbol{B}, \boldsymbol{D}, \boldsymbol{F}$, Hematoxylin- eosin muscles. $n=3$ muscles per genotype per time point.

ANOVA test for multiple comparisons, when applicable. $p$ values $<0.05$ were considered statistically significant.

\section{Results}

Muscle atrophy and decreased isometric twitch force in the twitcher mouse

Twitcher mice develop muscle weakness that progresses to paralysis of the lower limbs (hindlimbs or distal portion of limbs), most evident by P40. Muscle wasting affects muscles throughout the hindlimb, including the gastrocnemius, soleus, and TA muscles (Fig. $1 B$, arrows). To quantitate muscle wasting, we dissected and measured the mass of gastrocnemius muscles at different postnatal time points. Muscle wasting was significant as early as P15 and with a muscle mass decrease of $\sim 50 \%$ by P45 (Fig. $1 C$ ). To test whether muscle function was affected, we measured the 

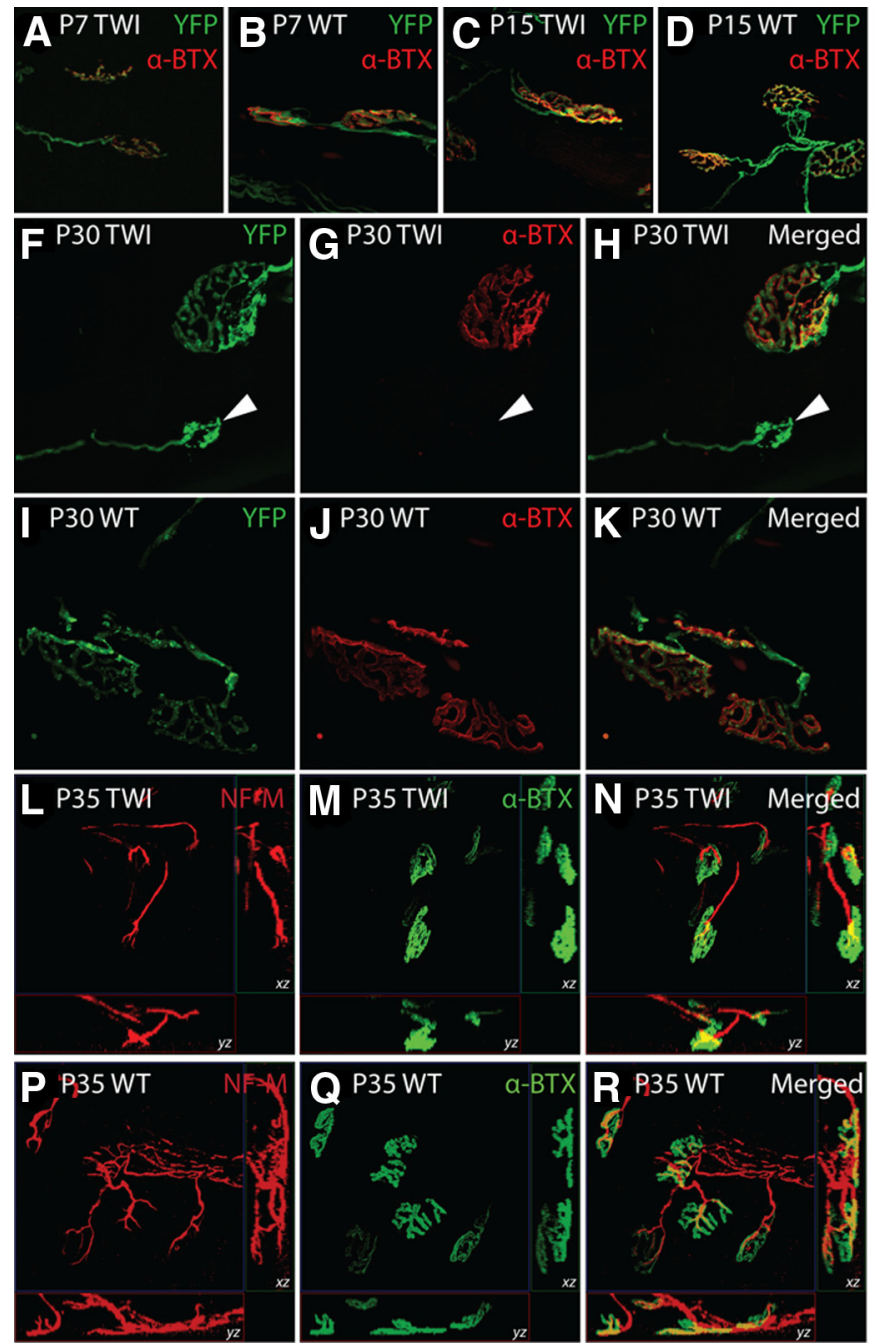

Figure 3. Absence of denervation in twitcher muscles. $\boldsymbol{A}-\boldsymbol{K}$, NMJs were detected by confocal imaging using soleus muscle preparations from the twitcher-YFPax and wild-type (WT) YFPax reporter mouse models at P7 $(\boldsymbol{A}, \boldsymbol{B}), \mathrm{P} 15(\boldsymbol{C}, \boldsymbol{D})$, and P30 (F-K) after staining postsynaptic neuromuscular membranes with Alexa Fluor-555 BTX (in red). Arrowhead points to a denervated NMJ in twitcher (TWI) muscle. $\boldsymbol{L}-\boldsymbol{R}$, Endplates were studied in whole-mount preparations of mutant and wild-type diaphragm muscles. Axons were labeled using anti-NF-M antibodies (in red) and Alexa Fluor-488 BTX (in green) and analyzed by confocal imaging and orthogonal reconstructions (planes $x-z, y-z$ ). $\boldsymbol{E}, \mathbf{0}$, The proportion (as percentage of the total) of complete denervated (BTX ${ }^{-} / \mathrm{YFP}^{+}$) and innervated (BTX ${ }^{+} / \mathrm{YFP}^{+}$) endplates in P30 soleus $(\boldsymbol{E})$ and P35 diaphragm (0) muscles was calculated and found not significantly different in twitcher mice ( $n=30-50$ NMJs per genotype).

maximal isometric force generated during a repeated train of nerve stimuli of TA muscles. Isometric twitching forces were significantly reduced as early as P15 (Fig. 2A).

\section{Fibrosis and reduction of muscle fiber size in the}

\section{twitcher mouse}

Gomori's trichrome staining revealed abundant deposits of collagenous material between mutant fibers in gastrocnemius muscles (Fig. 2C, arrows). Large numbers of clustered nuclei were also observed in the deposits, possibly indicating proliferating fibroblasts or infiltrating inflammatory cells. Signs of regeneration (e.g., central nuclei) were absent.

Fiber size analysis was done using serial sectioning along the longitudinal axis of the gastrocnemius muscle. Small-sized fibers were frequent in the twitcher muscle as early as P15 (Fig. 2B, asterisks). Measurement of the cross-sectional area showed that increases of the cross-sectional area were significantly greater in wild-type mice (Fig. 2F). No significant difference was measured between muscle fibers obtained from twitcher mice and wild- type mice at P7. However, at P15 and P30, there were significantly fewer large-caliber $\left(>700 \mu \mathrm{m}^{2}\right)$ fibers in twitcher mice.

\section{Axonal death and NMJ atrophy without major denervation in} twitcher muscles

Previous findings proved that twitcher peripheral nerves are affected by axonopathy (Castelvetri et al., 2011), a condition that could lead to the inactivation of the nerve terminals, and denervation. To investigate this possibility, first we analyzed how the disease affects the NMJ in distal muscles. Longitudinal sections of P7, P15, and P30 from soleus muscles were isolated from the twitcher-YFPax mouse, which allows detailed confocal analysis of $\mathrm{YFP}^{+}$axons (Castelvetri et al., 2011). Sections were labeled with Alexa Fluor-555 BTX, which binds to the $\alpha$-subunit of the AChR. Confocal imaging of $\mathrm{BTX}^{+} / \mathrm{YFP}^{+} \mathrm{NMJ}$ showed typical pretzel-like ramified structures in twitcher muscles, many of which were smaller than control NMJs (Fig. $3 A, C, F-H$ ). Unexpectedly, denervation (e.g., absence of BTX costaining of $\mathrm{YPF}^{+}$ endplates) was a rare finding in muscles from sick (P30) mutants 
(Fig. 3F-H, arrowhead) and completely absent at younger ages. Quantitative analysis confirmed the absence of significant denervation (Fig. 3E). To study denervation in proximal muscle groups and to control for any potential artifact that the YPF transgenic may have introduced, diaphragms from sick (P35) parental non-YFP twitcher mice and age-matched wild-type littermates were colabeled for NF-M (in red) and BTX (in green). Confocal orthogonal analysis showed similar findings, with smaller NF-M ${ }^{+}$axonal branches but nonsignificant denervation in twitcher diaphragms (Fig. $3 L-N$, quantitation in $O$ ). Confocal analysis did not reveal any sign of collateral branching in either in the twitcherYFPax or twitcher background.

Although denervation was not significant, we found axonal terminals in twitcher NMJ containing high levels of active caspase-3 (Fig. 4E-G, arrowhead). Activation of caspase-3 became significant as early as $\mathrm{P} 15$ (Fig. 4K). These results were in agreement with our previous report showing that caspases are activated in sciatic nerve axons from twitcher mice (Smith et al., 2011). Interestingly, mutant muscle cells did not stain for active caspase-3, suggesting that caspase-3mediated apoptosis is not a major component of muscle atrophy. This result was confirmed by the absence of TUNEL ${ }^{+}$muscle fibers from twitcher mice (data not shown).

Confocal $3 \mathrm{D}$ reconstruction was performed to measure for changes in NMJ surface and volume measured. Figure $5 \mathrm{~A}$ shows a reconstructed image of small NMJ from a P30 twitcher mouse. Small NMJs accounted for only $10 \%$ of the total number of NMJs in wild-type muscles but for $\sim 30 \%$ of the total number of NMJs in twitcher muscles (Fig. 5B). Mutant small NMJs had significant reductions in total surface (Fig. $5 C$ ) and volume (Fig. 5D).

\section{Expression of AChR- $\gamma$ characterizes failures in MEPPs in the} twitcher muscle

These results suggested that dysfunctional NMJs rather than denervation and muscle death mediate muscle atrophy in the twitcher mouse. To study this in more detail, we analyzed for changes in the subunit composition of the AChR. Gene expression analysis revealed a significant increase in AChR- $\gamma$ mRNA levels in mutant gastrocnemius as early as P15 (Fig. 5E). AChR- $\gamma$ subunit upregulation has been shown to occur subsequent to dysfunctional neuromuscular transmission (Pinter et al., 1995; Balice-Gordon et al., 2000; Kong et al., 2009) and is likely attributed to the same process in twitcher mice.

To measure for changes in neuromuscular transmission, we examined the properties of MEPP in nerve-muscle preparations. Control values obtained from wild-type mice were similar to those reported previously (Ribchester, 2011). As expected, there was a progression in the severity of the changes in electrophysiological events in twitcher mice from P15 to P30 (Fig. 6). The most significant change at P15 was a decrease in the frequency of MEPPs (Fig. 6D) and an increase in the rate constant of decay of the MEPPs compared with wild type (Fig. 6H). At P30, twitcher mice showed increased MEPP amplitude (Fig. 6J), decreased MEPP frequency (Fig. $6 L$ ), and increased rate constants of rise (Fig. 6N) and decay (Fig. 6P). Altogether, the changes in the
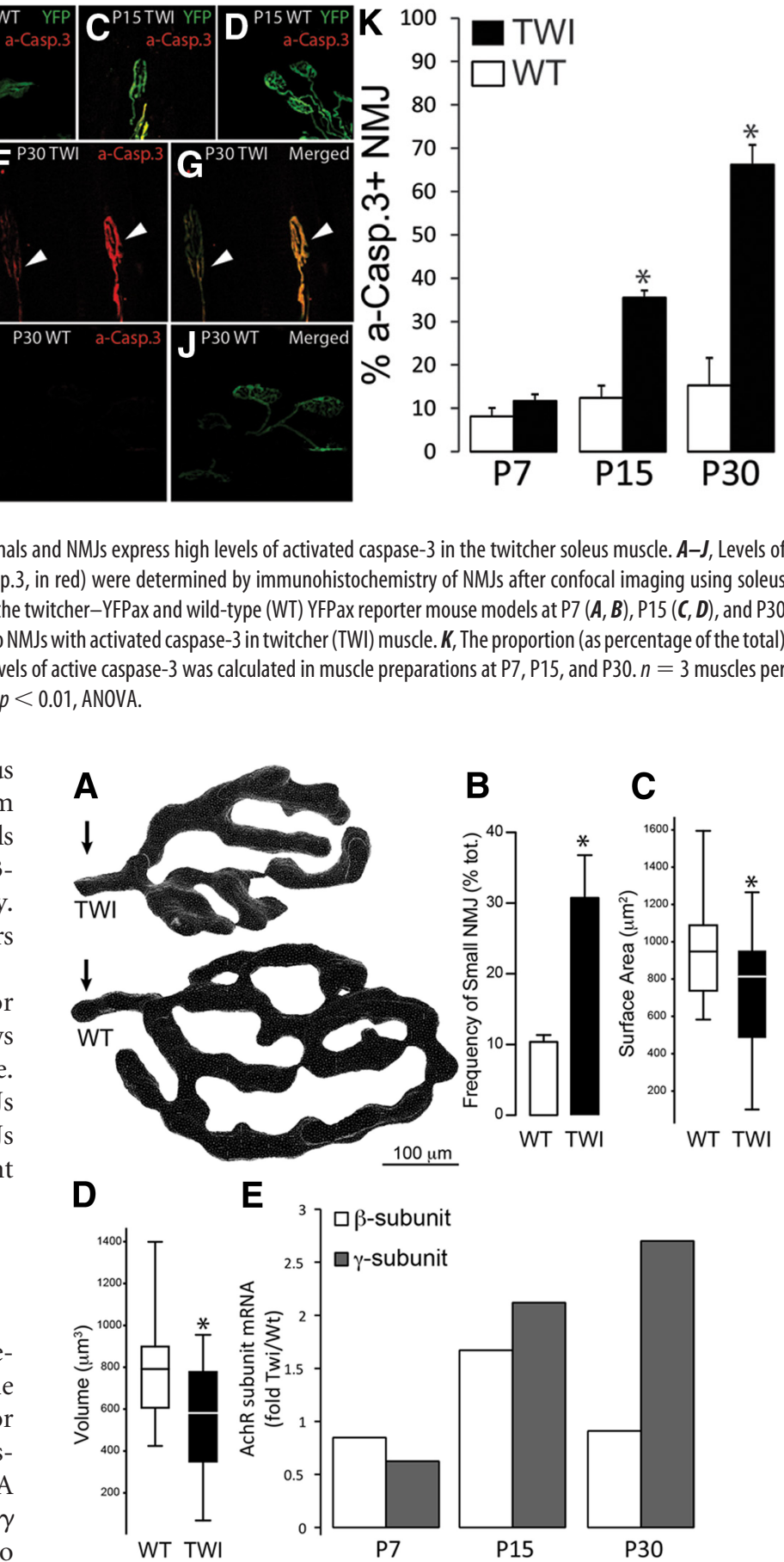

E $\quad 3] \square \beta$-subunit
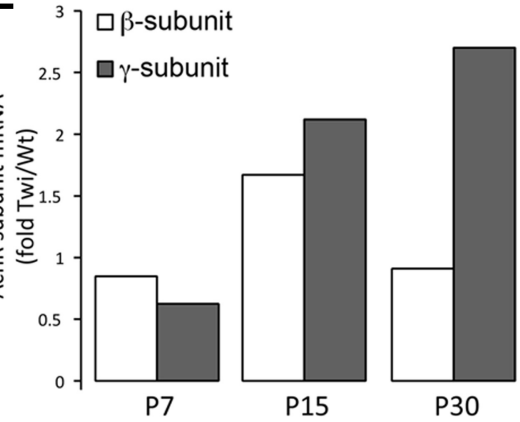

Figure 5. Soleus NMJs are atrophied in twitcher mice and re-express the AChR- $\gamma$ subunit. $A-D$, The morphology of NMJs was determined by $3 D$ confocal reconstruction of soleus muscle preparations from the twitcher-YFPax and wild-type YFPax reporter mouse model at P30. Images in $\boldsymbol{A}$ show two stereotypical reconstructed images for a twitcher (TWI) and wild-type (WT) NMJ. Images are at the same magnification. Arrows point to the axonal terminals of the junctions. The frequency of smaller NMJ (as percentage of the total, $\boldsymbol{B}$ ), the exposed surface area (in square micrometers, $\boldsymbol{C}$ ), and total volume (in cubic micrometers, $\boldsymbol{D}$ ) were calculated. $n=3$ muscles per genotype. ${ }^{*} p<0.05, t$ test). $\boldsymbol{E}$, The expression of the $\beta$ and $\gamma$ AChR subunit mRNA was analyzed by real-timePCR in RNA extracts from twitcher (TWI) and wild-type (WT) gastrocnemius muscles at P7, P15, and P30. Data are expressed as fold changes in twitcher over wild type.

properties of MEPPs reflect presynaptic and postsynaptic alterations and suggest that the neurotransmitter is released from the presynaptic terminal less frequently in the twitcher mouse. These observations also support a change in AChR sensitivity, likely 

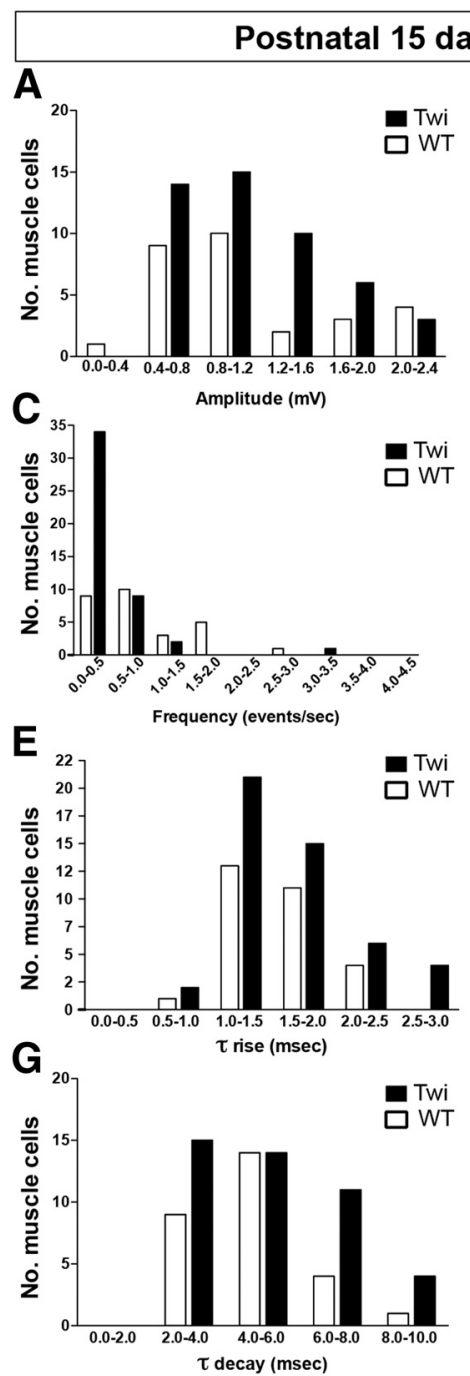
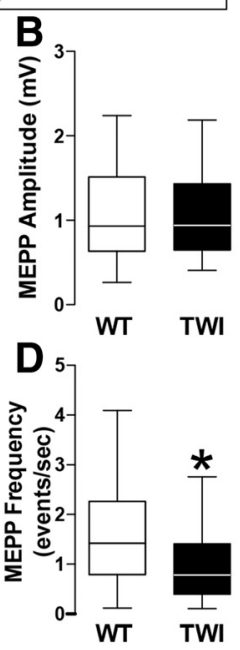

F
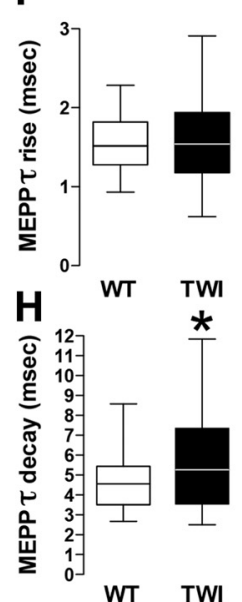

WT
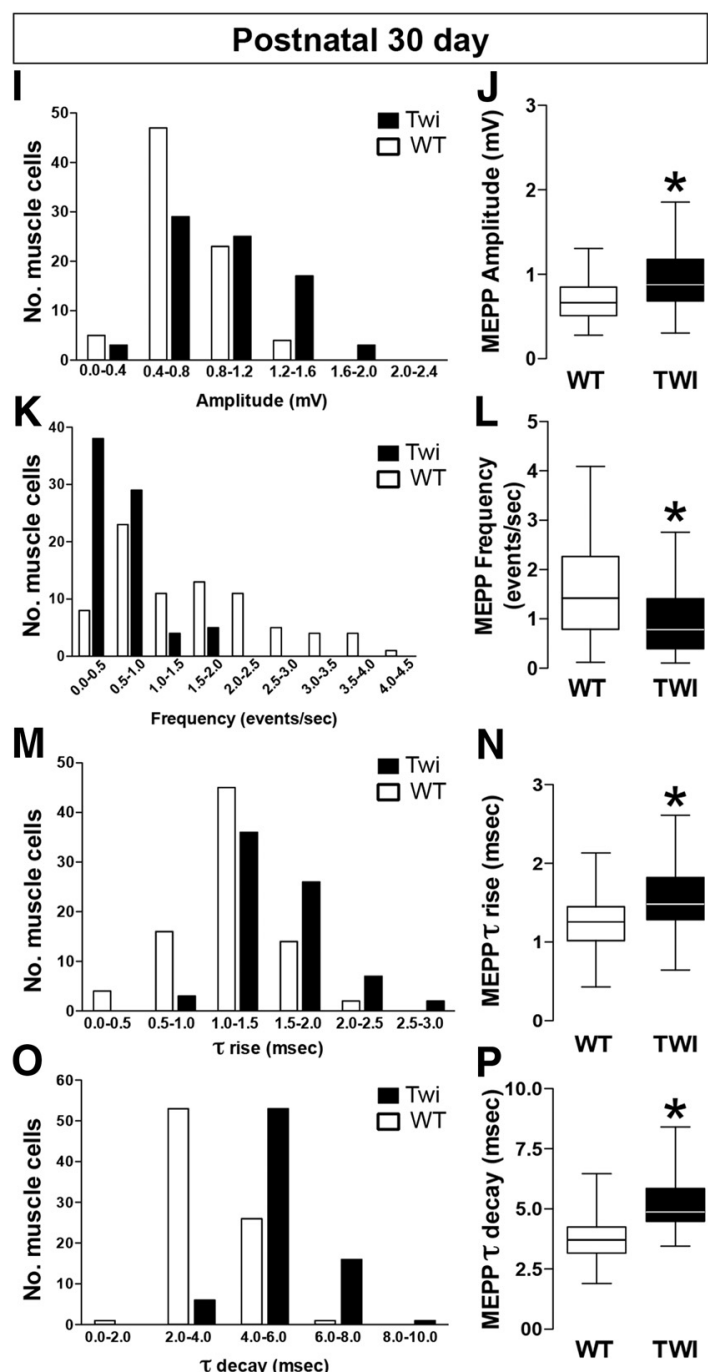

N
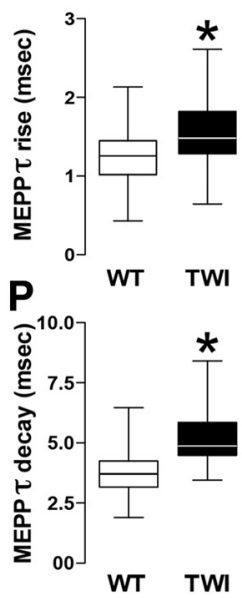

Figure 6. Extensor digitorum longus motor units exhibit synaptic failure in twitcher mice. MEPPs were recorded continuously on preparations of extensor digitorum longus isolated from P15 $(\boldsymbol{A}-\boldsymbol{H})$ and P30 (I-P) twitcher (Twi) and wild-type (WT) mice ( $n=6$ mice per genotype). Amplitude (in millivolts, $\boldsymbol{B}, \boldsymbol{J})$, frequency (in events per second, $\boldsymbol{D}, \boldsymbol{L})$, and rise $(\boldsymbol{F}, \boldsymbol{N})$ and decay $(\boldsymbol{H}, \boldsymbol{P})$ constants (in milliseconds) were calculated at each time point. Distribution histograms are shown in $\boldsymbol{A}, \boldsymbol{C}, \boldsymbol{E}, \boldsymbol{G}, \boldsymbol{I}, \boldsymbol{K}, \boldsymbol{M}$, and $\boldsymbol{O}$, indicating the number of muscle cells studied for each parameter. ${ }^{*} p<$ $0.01, t$ test.

because of the increase in expression of the AChR- $\gamma$ subunit (Vohra et al., 2006; Fig. 5E).

Decrease in Akt activity in the twitcher muscle

The previous findings show a progressive failure of the twitcher NMJ. This might negatively affect muscle physiology, leading to downstream metabolic changes that further compromise muscle maintenance. The growth of skeletal muscles is regulated by the balance between hypertrophy (anabolic) and atrophy (catabolic) signals. The kinase Akt emerged as a pivotal regulator of this balance (Bodine et al., 2001). To study whether the Akt pathway is altered in muscle from twitcher mice, phosphorylated Akt (ser473) levels in muscle were determined. Phosphorylation on ser473 is required for Akt activation and is therefore a useful indicator of the activation state of the kinase in muscle. As expected, levels of phosphorylated Akt increased in wild-type muscles (Fig. $7 A, B$ ). In contrast, phosphorylation was significantly reduced in $\mathrm{P} 15(\sim 70 \%)$ and $\mathrm{P} 30(\sim 80 \%)$ mutant muscle extracts (Fig. $7 A, B$ ), suggesting a decreased activation of Akt. Measuring phosphorylation levels (Ser9) of the Akt-downstream target GSK $3 \beta$ is an indirect reading for Akt activity. Figure 7, $A$ and $E$, underlines that muscles from twitcher mice have reduced levels of phosphorylated GSK3 $\beta$ as early as P15.

Repression of the protein synthesis machinery and increase in protein degradation

Downregulation of Akt activity negatively affects the activity of the translational repressor 4EBP1 (Bodine et al., 2001). Dephosphorylated 4EBP1 prevents the initiation of mRNA translation, therefore inhibiting protein synthesis. Levels of phosphorylated 4EBP1 were decreased in the muscle from twitcher mice, with significant reductions $(\sim 60 \%)$ observed at P30 (Fig. 7D). Loss of Akt activity also stimulates the expression of atrogin-1 [muscle atrophy F-box $(M A F b x)$ ], a muscle-specific ubiquitin ligase that is upregulated in several models of muscle atrophy and is thought to mediate the degradation of skeletal muscle proteins. MAFbx RNA levels were increased $\sim 1.5$ - and $\sim 14$-fold in P15 and P30 muscle from twitcher mice, respectively (Fig. 7C). MAFbx increase suggests the overactivation of the ubiquitination system and, consequently, of the proteasome degradation pathway. High levels 

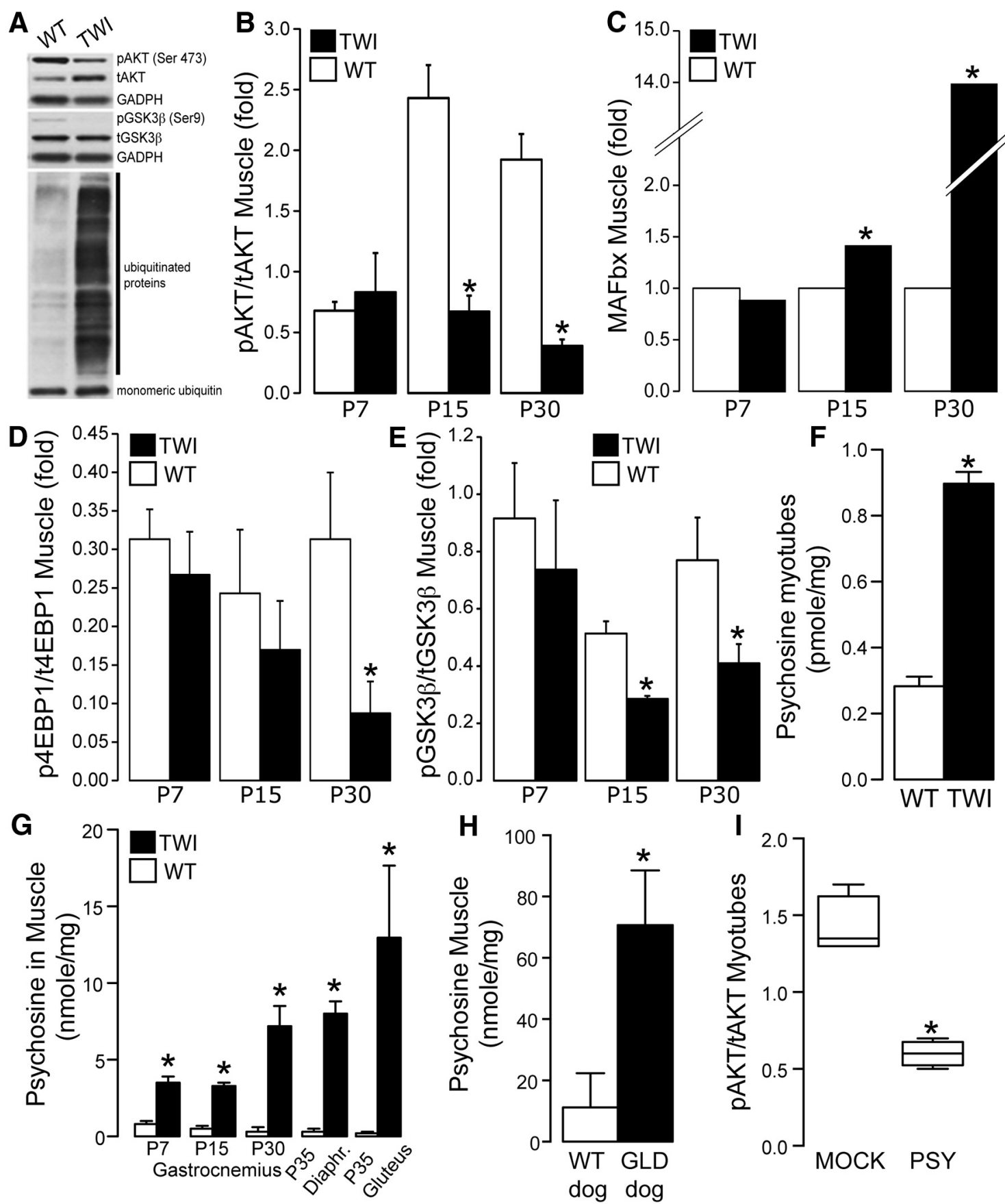

J

Psychosine

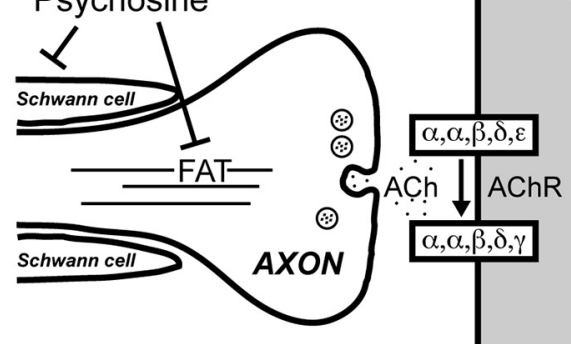

Psychosine

MUSCLE CELL

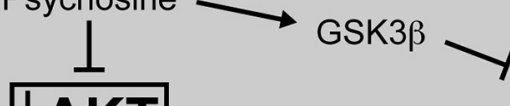

Protein Synthesis

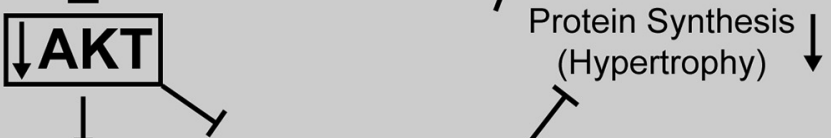

Atrogenes

mTOR -1 E-BP1

MAFbx

Ubiquitination

Protein Degradation $\uparrow$

(Atrophy) 
of ubiquitinated proteins in twitcher muscle extracts further confirmed this hypothesis (Fig. 7A).

\section{Psychosine as a contributor to muscle dysfunction in the twitcher mouse via Akt repression}

GALC deficiency leads to the accumulation of psychosine, which affects several signaling enzymes, such as GSK3 $\beta$ and protein kinase C. We asked whether psychosine could also contribute to muscle dysfunction. Psychosine levels were measured in acutely enriched primary cultures of differentiated myotubes prepared from wild-type and twitcher pups at P3. Tandem mass spectrometry revealed a twofold increase of psychosine in mutant myotubes (Fig. $7 F$ ), suggesting that mutant muscles accumulate psychosine in situ. Additional measurements showed that psychosine accumulated in distinct twitcher muscles early after birth (Fig. $7 G$ ). Moreover, psychosine was also elevated in the GLD dog gastrocnemius muscle (Fig. $7 H$ ), indicating that this phenotype is not species dependent but is disease related. Finally, to study whether psychosine affects the Akt phenotype observed in mutant muscles, acutely enriched cultures of wild-type myotubes were incubated with psychosine before determination of levels of phosphorylated (Ser473) Akt. Figure 7I shows that psychosinetreated myotubes contained significantly lower levels of phosphorylated Akt. These results underline the possibility that in situ accumulation of psychosine in mutant muscle fibers contributes to Akt inactivation and muscle wasting.

\section{Discussion}

This study reports key elements of a complex pathogenic mechanism affecting the function, structure, and growth of skeletal muscles in Krabbe disease. Our results identified both presynaptic and postsynaptic defects in the NMJ of the twitcher mouse and indicate that psychosine contributes to muscle pathology by decreasing Akt in mutant muscles.

Motor deficiency is a hallmark in all untreated Krabbe patients (Krabbe, 1916), who undergo hypokinesia, muscle wasting, and atrophy. The twitcher mouse displays similar problems with twitching, hypokinesia, muscle loss (particularly in hindlimbs), and eventually paralysis (Duchen et al., 1980; Kobayashi et al., 1980; Castelvetri et al., 2011). Although muscle wasting is an expected

\section{$\leftarrow$}

Figure 7. Defective Akt signaling drives muscle atrophy in twitcher mice. $\boldsymbol{A}-\boldsymbol{E}$, Protein extracts were prepared from gastrocnemius muscles from twitcher (TWI) and wild-type (WT) mice at P7, P15, and P30. Extracts were immunoblotted for phosphorylated (Ser473; $\boldsymbol{A}$ ) and total (B) Akt, phosphorylated and total 4EBP1 (D), and phosphorylated (Ser9) and total (E) GSK3 $\beta$. Real-time PCR measured the abundance of mRNA for the MAFbx gene $(\boldsymbol{C}) . n=3$ muscles per genotype per time point. ${ }^{*} p<0.01$, ANOVA. $\boldsymbol{F}-\boldsymbol{H}$, Psychosine was measured by tandem mass spectrometry in differentiated cultures of myotubes $(\boldsymbol{F})$ and total lipid extracts from gastrocnemius, gluteus, and diaphragm muscles in twitcher $(\boldsymbol{G})$ and GLD $(\boldsymbol{H})$ animals. Age-matched controls were used for each determination. $n=3-4$ muscles (or culture extracts) per genotype per time point. ${ }^{*} p<0.01$, ANOVA and $t$ test. I, Cultures of wild-type myotubes were incubated with $5 \mu \mathrm{m}$ psychosine (PSY) or with a mock vehicle $(0.005 \%$ ethanol/PBS) solution before measuring the level of phosphorylation of Akt by immunoblotting. $n=3$ samples per experimental condition point. ${ }^{*} p<0.05, t$ test. $J$, The illustration proposes a mechanistic model of muscle atrophy in Krabbe disease, including the key elements described by the analyses of the twitcher mouse. Psychosine is likely acting at multiple levels, by blocking fast axonal transport (FAT) in motor axons, affecting myelin and Schwann cells in peripheral nerves, and repressing Akt activation in muscle cells. Deficient electrical conduction at the endplate likely drives the re-expression of the embryonic AChR- $\gamma$ subunit at the postsynaptic membrane, contributing to inefficient neuromuscular activity. Reduced endplate activity in conjunction with in situ accumulation of psychosine reduces Akt activity further, driving twitcher muscles toward atrophy via proteosome degradation and reducing muscle hypertrophy via protein synthesis shutdown. p, Phosphorylated; t, total. outcome in most leukodystrophies, the structural, functional, and metabolic changes underlying muscle defects in Krabbe disease were unexplored. An understanding of muscle pathology is essential to developing therapies that address all signs of disease, including myopathy.

In this study, we demonstrate that twitcher muscles are fibrotic and contain fewer large fibers, and remnant fibers are weaker. Fibrosis is an important component in myopathies (Mendias et al., 2012) and is often observed after denervation, as a response to replace muscle cell loss. However, our study did not find evidence of major denervation in twitcher mice. Denervation was not significantly high even in very sick mice undergoing more evident signs of paralysis of the lower limbs. Muscle atrophy in the absence of clear denervation has been observed in some conditions, such as myasthenia gravis and Lambert-Eaton myasthenic syndrome (Pinter et al., 1995; Balice-Gordon et al., 2000; Kong et al., 2009). One interpretation from these results is that muscle wasting is a consequence of dysfunctional NMJs rather than the complete physical loss of NMJ contact.

Structural analyses of twitcher NMJs confirmed the presence of abnormal endplates with reduced nerve-muscle contact area. Two potential explanations are that NMJs from twitcher mice do not undergo complete maturation or they undergo atrophy. Various factors may contribute to NMJ dysfunction. For example, activation of effector caspases leads to instability of the endplate cytoskeleton and NMJ structural alterations (Vohra et al., 2004, 2006). Analysis of activated caspase- 3 in twitcher muscle revealed high levels of activated caspase-3 affecting $\sim 70 \%$ of NMJs in symptomatic twitcher mice. Despite this observation, analysis of cell death activation in twitcher muscle fibers was negative, indicating that cell death of the muscle fiber is not a key element in the disease. This finding is supported by previous observations of high levels of this effector caspase in twitcher peripheral axons, in the absence of major neuronal death in the spinal cord (Castelvetri et al., 2011; Smith et al., 2011). Caspase-3, a well known mediator of cell death, has additional non-apoptotic functions in the CNS regulating long-term potentiation and synaptic plasticity in the brain (Li et al., 2010; Jo et al., 2011; Forrest et al., 2013). Although caspase- 3 activity is essential for proper development of synapses, its overactivation has been implicated in several lateonset neurological disorders with severe synaptic dysfunction ( $\mathrm{Su}$ et al., 2001; Martin et al., 2002). Thus, our results suggest that there is a defect in the maturation (or even partial degeneration) of the presynaptic component of the NMJ. These defects likely contribute to postsynaptic changes.

Abnormal NMJ function and decreased conduction of nerve impulses to muscle could play a role in the immaturity of twitcher muscles and to the predominance of small muscle fibers found in this study. Fiber-type disproportion has been observed in children with Krabbe disease previously (Martin et al., 1976; Dehkharghani et al., 1981; Marjanović et al., 1996). The development of functional muscle requires connection and activity between muscle cells and nerve endings (Witzemann, 2006). The contact and the exchange of signals between growing neurites and muscle cells direct structural and functional organization of the NMJ (Punga and Ruegg, 2012). A key event in muscle development is the switch in gene expression from the $\gamma$ to the $\varepsilon$ subunits of the AChR, which represents the transition from the fetal ( $\gamma$ subunit) to the mature ( $\varepsilon$ subunit) form of the AChR. The $\gamma$ subunit is required for the nerve-induced clustering of the AChR, but its expression is suppressed when the NMJ is electrically active and releasing ACh (Numberger et al., 1991; Duclert and Changeux, 1995). Most muscle denervation conditions cause the reappear- 
ance of the AChR- $\gamma$ subunit, making this a marker of NMJ disease (Numberger et al., 1991). Because absolute denervation is not evident in muscles from twitcher mice, it is possible that mutant muscle fibers attempt to preserve NMJ responses by upregulation of the AChR- $\gamma$ subunit. The presence of the AChR- $\gamma$ subunit helps explain the changes in amplitude and kinetics of MEPPs. Although responses from mature AChRs are larger than those of fetal AChRs, the fetal $\gamma$ subunit confers a higher affinity of the receptor to $\mathrm{ACh}$, especially at low concentrations (Vohra et al., 2006). Such a low concentration can be achieved by decreasing the frequency of $\mathrm{ACh}$ release together with a reduction in the contact surface and volume of the NMJ. The extended open times of AChR- $\gamma$ with respect to those measured for AChR- $\varepsilon$ (Vohra et al., 2004, 2006; Tews, 2005) support the increase in the rate constant of decay found in our study, particularly during the symptomatic stage of the disease.

Although it seems clear that a major component of muscle wasting in Krabbe disease is attributable to extrinsic defects affecting the structure and function of axons and NMJs, our results also reveal possible intrinsic muscle defects. Our findings that psychosine is accumulated in isolated twitcher myotubes suggest that it may also interfere with key signals for muscle growth, such as Akt. The maintenance of a healthy skeletal muscle is highly dependent on the activity of Akt, which acts as a molecular switch between protein synthesis and protein degradation, thereby determining the overall growth of muscle mass (Dobrowolny et al., 2011; Alessi et al., 1996; Bodine et al., 2001; Millino et al., 2009). The involvement of Akt in neuronal and oligodendroglial defects in Krabbe disease has been indicated by previous reports (Zaka et al., 2005; Teixeira et al., 2014), but its role in muscle wasting was not reported. One of the functional consequences of low Akt activity in muscle cells is the increase in ubiquitination of muscle proteins and their degradation (Glass, 2003a,b). Akt regulates protein degradation via phosphorylation of FoxO transcription factors, which control the expression of several muscle-specific ubiquitin ligases, such as muscle ring finger 1 and MAFbx (or atrogin-1; Sandri et al., 2004; Stitt et al., 2004). In conditions of low Akt activity, muscle proteins are tagged for proteasome degradation. Akt also regulates muscle growth via mammalian target of rapamycin and GSK3 $\beta$ activities. Both proteins phosphorylate components of the translation machinery, therefore regulating the efficiency of the translation of mRNAs in the muscle cells (Sandri et al., 2004; Schiaffino et al., 2013) and increasing the rate of protein synthesis. Accumulation of psychosine in muscle cells may be a contributing factor to repress muscle growth via Akt downregulation. Psychosine may also have other additional pathogenic complications. Psychosine is known to affect mitochondrial activity (Strasberg, 1986), but how this translates into changes of energy metabolism is still unclear. Starvation and low food intake, which may be a major problem in Krabbe disease, are known to directly affect glucose and energy metabolism (Meisingset et al., 2013). Energy deprivation, a situation that affects other myelin diseases (Bakshi et al., 1998; Blüml et al., 2001), may be an important modulator of the intensity of muscle wasting in Krabbe disease.

Together with previous reports, our study demonstrates the existence of a pathogenic mechanism of muscle dysfunction in Krabbe disease involving (1) decreased peripheral nerve conduction (Dolcetta et al., 2005), (2) peripheral demyelination (Kondo et al., 1988) and neuropathy (Smith et al., 2011), (3) activation of caspases in presynaptic terminals, (4) dysfunctional MEPPs, (5) altered AChR composition, and (6) repression of the Akt pathway (Fig. $7 J$ ). The finding of low levels of Akt identifies a poten- tially interesting therapeutic target. In vivo and in vitro studies have demonstrated that activation of Akt leads to muscle fiber growth, (Bodine et al., 2001; Pallafacchina et al., 2002; Lai et al., 2004; Stitt et al., 2004). Thus, ectopic activation of the Akt pathway via small molecules such as SC79 (Jo et al., 2012) may cooperate positively and synergize with hematopoietic replacement and gene therapy, aiding to prevent motor deterioration in Krabbe disease.

\section{References}

Alden KJ, García J (2001) Differential effect of gabapentin on neuronal and muscle calcium currents. J Pharmacol Exp Ther 297:727-735. Medline

Alessi DR, Andjelkovic M, Caudwell B, Cron P, Morrice N, Cohen P, Hemmings BA (1996) Mechanism of activation of protein kinase B by insulin and IGF-1. EMBO J 15:6541-6551. Medline

Bakshi R, Miletich RS, Kinkel PR, Emmet ML, Kinkel WR (1998) Highresolution fluorodeoxyglucose positron emission tomography shows both global and regional cerebral hypometabolism in multiple sclerosis. J Neuroimaging 8:228-234. Medline

Balice-Gordon RJ, Smith DB, Goldman J, Cork LC, Shirley A, Cope TC, Pinter MJ (2000) Functional motor unit failure precedes neuromuscular degeneration in canine motor neuron disease. Ann Neurol 47:596605. CrossRef Medline

Blüml S, Moreno A, Hwang JH, Ross BD (2001) 1-(13)C glucose magnetic resonance spectroscopy of pediatric and adult brain disorders. NMR Biomed 14:19-32. CrossRef Medline

Bodine SC, Stitt TN, Gonzalez M, Kline WO, Stover GL, Bauerlein R, Zlotchenko E, Scrimgeour A, Lawrence JC, Glass DJ, Yancopoulos GD (2001) Akt/mTOR pathway is a crucial regulator of skeletal muscle hypertrophy and can prevent muscle atrophy in vivo. Nat Cell Biol 3:1014-1019. CrossRef Medline

Campisi P, Egiazarian K (2007) Blind image deconvolution: theory and applications. Boca Raton, FL: CRC.

Cantuti Castelvetri L, Givogri MI, Hebert A, Smith B, Song Y, Kaminska A, Lopez-Rosas A, Morfini G, Pigino G, Sands M, Brady ST, Bongarzone ER (2013) The sphingolipid psychosine inhibits fast axonal transport in Krabbe disease by activation of GSK3beta and deregulation of molecular motors. J Neurosci 33:10048-10056. CrossRef Medline

Cantuti-Castelvetri L, Zhu H, Givogri MI, Chidavaenzi RL, Lopez-Rosas A, Bongarzone ER (2012) Psychosine induces the dephosphorylation of neurofilaments by deregulation of PP1 and PP2A phosphatases. Neurobiol Dis 46:325-335. CrossRef Medline

Castelvetri LC, Givogri MI, Zhu H, Smith B, Lopez-Rosas A, Qiu X, van Breemen R, Bongarzone ER (2011) Axonopathy is a compounding factor in the pathogenesis of Krabbe disease. Acta Neuropathol 122:35-48. CrossRef Medline

Chen G, Bower KA, Ma C, Fang S, Thiele CJ, Luo J (2004) Glycogen synthase kinase 3beta (GSK3beta) mediates 6-hydroxydopamine-induced neuronal death. FASEB J 18:1162-1164. CrossRef Medline

Dehkharghani F, Sarnat HB, Brewster MA, Roth SI (1981) Congenital muscle fiber-type disproportion in Krabbe's leukodystrophy. Arch Neurol 38:585-587. CrossRef Medline

Dobrowolny G, Aucello M, Musarò A (2011) Muscle atrophy induced by SOD1G93A expression does not involve the activation of caspase in the absence of denervation. Skelet Muscle 1:3. CrossRef Medline

Dolcetta D, Amadio S, Guerrini U, Givogri MI, Perani L, Galbiati F, Sironi L, Del Carro U, Roncarolo MG, Bongarzone E (2005) Myelin deterioration in Twitcher mice: motor evoked potentials and magnetic resonance imaging as in vivo monitoring tools. J Neurosci Res 81:597-604. CrossRef Medline

Duchen LW, Eicher EM, Jacobs JM, Scaravilli F, Teixeira F (1980) Hereditary leucodystrophy in the mouse: the new mutant twitcher. Brain 103: 695-710. CrossRef Medline

Duclert A, Changeux JP (1995) Acetylcholine receptor gene expression at the developing neuromuscular junction. Physiol Rev 75:339-368. Medline

Escolar ML, Poe MD, Provenzale JM, Richards KC, Allison J, Wood S, Wenger DA, Pietryga D, Wall D, Champagne M, Morse R, Krivit W, Kurtzberg J (2005) Transplantation of umbilical-cord blood in babies with infantile Krabbe's disease. N Engl J Med 352:2069-2081. CrossRef Medline 
Fang Q, Boas DA (2009) Tetrahedral mesh generation from volumetric binary and gray-scale images. In: Proceedings of the Sixth IEEE International Conference on Symposium on Biomedical Imaging: From Nano to Macro, pp 1142-1145. Boston: IEEE.

Feng G, Mellor RH, Bernstein M, Keller-Peck C, Nguyen QT, Wallace M, Nerbonne JM, Lichtman JW, Sanes JR (2000) Imaging neuronal subsets in transgenic mice expressing multiple spectral variants of GFP. Neuron 28:41-51. CrossRef Medline

Forrest CM, Darlington LG, Stone TW (2013) Involvement of the proteasome and caspase activation in hippocampal long-term depression induced by the serine protease subtilisin. Neuroscience 231:233-246. CrossRef Medline

Galbiati F, Basso V, Cantuti L, Givogri MI, Lopez-Rosas A, Perez N, Vasu C, Cao H, van Breemen R, Mondino A, Bongarzone ER (2007) Autonomic denervation of lymphoid organs leads to epigenetic immune atrophy in a mouse model of Krabbe disease. J Neurosci 27:13730-13738. CrossRef Medline

Galbiati F, Givogri MI, Cantuti L, Rosas AL, Cao H, van Breemen R, Bongarzone ER (2009) Combined hematopoietic and lentiviral gene-transfer therapies in newborn Twitcher mice reveal contemporaneous neurodegeneration and demyelination in Krabbe disease. J Neurosci Res 87:17481759. CrossRef Medline

Glass DJ (2003a) Signalling pathways that mediate skeletal muscle hypertrophy and atrophy. Nat Cell Biol 5:87-90. CrossRef Medline

Glass DJ (2003b) Molecular mechanisms modulating muscle mass. Trends Mol Med 9:344-350. CrossRef Medline

Gosmanov AR, Umpierrez GE, Karabell AH, Cuervo R, Thomason DB (2004) Impaired expression and insulin-stimulated phosphorylation of Akt-2 in muscle of obese patients with atypical diabetes. Am J Physiol Endocrinol Metab 287:E8-E15. CrossRef Medline

Igisu H, Suzuki K (1984) Progressive accumulation of toxic metabolite in a genetic leukodystrophy. Science 224:753-755. CrossRef Medline

Jo H, Mondal S, Tan D, Nagata E, Takizawa S, Sharma AK, Hou Q, Shanmugasundaram K, Prasad A, Tung JK, Tejeda AO, Man H, Rigby AC, Luo HR (2012) Small molecule-induced cytosolic activation of protein kinase Akt rescues ischemia-elicited neuronal death. Proc Natl Acad Sci U S A 109:10581-10586. CrossRef Medline

Jo J, Whitcomb DJ, Olsen KM, Kerrigan TL, Lo SC, Bru-Mercier G, Dickinson B, Scullion S, Sheng M, Collingridge G, Cho K (2011) Abeta(1-42) inhibition of LTP is mediated by a signaling pathway involving caspase-3, Akt1 and GSK-3beta. Nat Neurosci 14:545-547. CrossRef Medline

Kobayashi T, Yamanaka T, Jacobs JM, Teixeira F, Suzuki K (1980) The Twitcher mouse: an enzymatically authentic model of human globoid cell leukodystrophy (Krabbe disease). Brain Res 202:479-483. CrossRef Medline

Kondo A, Hoogerbrugge PM, Suzuki K, Poorthuis BJ, Van Bekkum DW, Suzuki K (1988) Pathology of the peripheral nerve in the twitcher mouse following bone marrow transplantation. Brain Res 460:178-183. CrossRef Medline

Kong L, Wang X, Choe DW, Polley M, Burnett BG, Bosch-Marcé M, Griffin JW, Rich MM, Sumner CJ (2009) Impaired synaptic vesicle release and immaturity of neuromuscular junctions in spinal muscular atrophy mice. J Neurosci 29:842-851. CrossRef Medline

Krabbe K (1916) A new familial, infantile form of diffuse brain. sclerosis. Brain 39:74-114. CrossRef

Krivit W, Shapiro EG, Peters C, Wagner JE, Cornu G, Kurtzberg J, Wenger DA, Kolodny EH, Vanier MT, Loes DJ, Dusenbery K, Lockman LA (1998) Hematopoietic stem-cell transplantation in globoid-cell leukodystrophy. N Engl J Med 338:1119-1126. CrossRef Medline

Lai KM, Gonzalez M, Poueymirou WT, Kline WO, Na E, Zlotchenko E, Stitt TN, Economides AN, Yancopoulos GD, Glass DJ (2004) Conditional activation of akt in adult skeletal muscle induces rapid hypertrophy. Mol Cell Biol 24:9295-9304. CrossRef Medline

Léger B, Vergani L, Sorarù G, Hespel P, Derave W, Gobelet C, D’Ascenzio C, Angelini C, Russell AP (2006a) Human skeletal muscle atrophy in amyotrophic lateral sclerosis reveals a reduction in Akt and an increase in atrogin-1. FASEB J 20:583-585. CrossRef Medline

Léger B, Cartoni R, Praz M, Lamon S, Dériaz O, Crettenand A, Gobelet C, Rohmer P, Konzelmann M, Luthi F, Russell AP (2006b) Akt signalling through GSK-3beta, mTOR and Foxol is involved in human skeletal muscle hypertrophy and atrophy. J Physiol 576:923-933. CrossRef Medline
Li Z, Jo J, Jia JM, Lo SC, Whitcomb DJ, Jiao S, Cho K, Sheng M (2010) Caspase- 3 activation via mitochondria is required for long-term depression and AMPA receptor internalization. Cell 141:859-871. CrossRef Medline

Livak KJ, Schmittgen TD (2001) Analysis of relative gene expression data using real-time quantitative PCR and the 2(-Delta Delta C(T)) method. Methods 25:402-408. CrossRef Medline

Luzi P, Rafi MA, Zaka M, Rao HZ, Curtis M, Vanier MT, Wenger DA (2005) Biochemical and pathological evaluation of long-lived mice with globoid cell leukodystrophy after bone marrow transplantation. Mol Genet Metab 86:150-159. CrossRef Medline

Marjanović B, Cvetković D, Dozić S, Todorović S, Djurić M (1996) Association of Krabbe leukodystrophy and congenital fiber type disproportion. Pediatr Neurol 15:79-82. CrossRef Medline

Martin DS, Lonergan PE, Boland B, Fogarty MP, Brady M, Horrobin DF, Campbell VA, Lynch MA (2002) Apoptotic changes in the aged brain are triggered by interleukin-1beta-induced activation of $\mathrm{p} 38$ and reversed by treatment with eicosapentaenoic acid. J Biol Chem 277:34239-34246. CrossRef Medline

Martin JJ, Clara R, Ceuterick C, Joris C (1976) Is congenital fibre type disproportion a true myopathy? Acta Neurol Belg 76:335-344. Medline

McCurdy CE, Cartee GD (2005) Akt2 is essential for the full effect of calorie restriction on insulin-stimulated glucose uptake in skeletal muscle. Diabetes 54:1349-1356. CrossRef Medline

Meisingset TW, Ricca A, Neri M, Sonnewald U, Gritti A (2013) Region- and age-dependent alterations of glial-neuronal metabolic interactions correlate with CNS pathology in a mouse model of globoid cell leukodystrophy. J Cereb Blood Flow Metab 33:1127-1137. CrossRef Medline

Mendias CL, Gumucio JP, Davis ME, Bromley CW, Davis CS, Brooks SV (2012) Transforming growth factor-beta induces skeletal muscle atrophy and fibrosis through the induction of atrogin-1 and scleraxis. Muscle Nerve 45:55-59. CrossRef Medline

Millino C, Fanin M, Vettori A, Laveder P, Mostacciuolo ML, Angelini C, Lanfranchi G (2009) Different atrophy-hypertrophy transcription pathways in muscles affected by severe and mild spinal muscular atrophy. BMC Med 7:14. CrossRef Medline

Nédélec F, Surrey T, Maggs AC (2001) Dynamic concentration of motors in microtubule arrays. Phys Rev Lett 86:3192-3195. CrossRef Medline

Numberger M, Dürr I, Kues W, Koenen M, Witzemann V (1991) Different mechanisms regulate muscle-specific AChR gamma- and epsilon-subunit gene expression. EMBO J 10:2957-2964. Medline

Pallafacchina G, Calabria E, Serrano AL, Kalhovde JM, Schiaffino S (2002) A protein kinase B-dependent and rapamycin-sensitive pathway controls skeletal muscle growth but not fiber type specification. Proc Natl Acad Sci U S A 99:9213-9218. CrossRef Medline

Pinter MJ, Waldeck RF, Wallace N, Cork LC (1995) Motor unit behavior in canine motor neuron disease. J Neurosci 15:3447-3457. Medline

Powell HC, Knobler RL, Myers RR (1983) Peripheral neuropathy in the Twitcher mutant. A new experimental model of endoneurial edema. Lab Invest 49:19-25. Medline

Punga AR, Ruegg MA (2012) Signaling and aging at the neuromuscular synapse: lessons learnt from neuromuscular diseases. Curr Opin Pharmacol 12:340-346. CrossRef Medline

Reddy AS, Kim JH, Hawkins-Salsbury JA, Macauley SL, Tracy ET, Vogler CA, Han X, Song SK, Wozniak DF, Fowler SC, Klein RS, Sands MS (2011) Bone marrow transplantation augments the effect of brain- and spinal cord-directed adeno-associated virus $2 / 5$ gene therapy by altering inflammation in the murine model of globoid-cell leukodystrophy. J Neurosci 31:9945-9957. CrossRef Medline

Ribchester RR (2011) Quantal analysis of endplate potentials in mouse flexor digitorum brevis muscle. Curr Protoc Mouse Biol 1:429-444. CrossRef

Sakai N, Inui K, Tatsumi N, Fukushima H, Nishigaki T, Taniike M, Nishimoto J, Tsukamoto H, Yanagihara I, Ozono K, Okada S (1996) Molecular cloning and expression of cDNA for murine galactocerebrosidase and mutation analysis of the twitcher mouse, a model of Krabbe's disease. J Neurochem 66:1118-1124. CrossRef Medline

Sandri M, Sandri C, Gilbert A, Skurk C, Calabria E, Picard A, Walsh K, Schiaffino S, Lecker SH, Goldberg AL (2004) Foxo transcription factors induce the atrophy-related ubiquitin ligase atrogin-1 and cause skeletal muscle atrophy. Cell 117:399-412. CrossRef Medline

Schiaffino S, Dyar KA, Ciciliot S, Blaauw B, Sandri M (2013) Mechanisms 
regulating skeletal muscle growth and atrophy. FEBS J 280:4294-4314. CrossRef Medline

Smith BR, Santos MB, Marshall MS, Cantuti-Castelvetri L, Lopez-Rosas A, Li G, van Breemen R, Claycomb KI, Gallea JI, Celej MS, Crocker SJ, Givogri MI, Bongarzone ER (2014) Neuronal inclusions of alpha-synuclein contribute to the pathogenesis of Krabbe disease. J Pathol 232:509-521. CrossRef Medline

Smith B, Galbiati F, Castelvetri LC, Givogri MI, Lopez-Rosas A, Bongarzone ER (2011) Peripheral neuropathy in the Twitcher mouse involves the activation of axonal caspase 3. ASN Neuro 3:213-222. CrossRef Medline

Stitt TN, Drujan D, Clarke BA, Panaro F, Timofeyva Y, Kline WO, Gonzalez M, Yancopoulos GD, Glass DJ (2004) The IGF-1/PI3K/Akt pathway prevents expression of muscle atrophy-induced ubiquitin ligases by inhibiting FOXO transcription factors. Mol Cell 14:395-403. CrossRef Medline

Strasberg P (1986) Cerebrosides and psychosine disrupt mitochondrial functions. Biochem Cell Biol 64:485-489. Medline

Su JH, Zhao M, Anderson AJ, Srinivasan A, Cotman CW (2001) Activated caspase- 3 expression in Alzheimer's and aged control brain: correlation with Alzheimer pathology. Brain Res 898:350-357. CrossRef Medline

Suzuki K (2003) Globoid cell leukodystrophy (Krabbe's disease): update. J Child Neurol 18:595-603. CrossRef Medline

Takahashi H, Suzuki K (1984) Demyelination in the spinal cord of murine globoid cell leukodystrophy (the twitcher mouse). Acta Neuropathol 62: 298-308. CrossRef Medline

Tanaka K, Nagara H, Kobayashi T, Goto I (1988) The twitcher mouse: accumulation of galactosylsphingosine and pathology of the sciatic nerve. Brain Res 454:340-346. CrossRef Medline

Taniike M, Suzuki K (1994) Spacio-temporal progression of demyelination in twitcher mouse: with clinico-pathological correlation. Acta Neuropathol 88:228-236. CrossRef Medline

Teixeira CA, Miranda CO, Sousa VF, Santos TE, Malheiro AR, Solomon M, Maegawa GH, Brites P, Sousa MM (2014) Early axonal loss accompa- nied by impaired endocytosis, abnormal axonal transport, and decreased microtubule stability occur in the model of Krabbe's disease. Neurobiol Dis 66:92-103. CrossRef Medline

Tews DS (2005) Muscle-fiber apoptosis in neuromuscular diseases. Muscle Nerve 32:443-458. CrossRef Medline

Toyoshima E, Yeager AM, Brennan S, Santos GW, Moser HW, Mayer RF (1986) Nerve conduction studies in the Twitcher mouse (murine globoid cell leukodystrophy). J Neurol Sci 74:307-318. CrossRef Medline

Vohra BP, Groshong JS, Maselli RA, Verity MA, Wollmann RL, Gomez CM (2004) Focal caspase activation underlies the endplate myopathy in slowchannel syndrome. Ann Neurol 55:347-352. CrossRef Medline

Vohra BP, Groshong JS, Zayas R, Wollmann RL, Gomez CM (2006) Activation of apoptotic pathways at muscle fiber synapses is circumscribed and reversible in a slow-channel syndrome model. Neurobiol Dis 23:462470. CrossRef Medline

Wenger DA, Rafi MA, Luzi P, Datto J, Costantino-Ceccarini E (2000) Krabbe disease: genetic aspects and progress toward therapy. Mol Genet Metab 70:1-9. CrossRef Medline

White AB, Givogri MI, Lopez-Rosas A, Cao H, van Breemen R, Thinakaran G, Bongarzone ER (2009) Psychosine accumulates in membrane microdomains in the brain of krabbe patients, disrupting the raft architecture. J Neurosci 29:6068-6077. CrossRef Medline

Witzemann V (2006) Development of the neuromuscular junction. Cell Tissue Res 326:263-271. CrossRef Medline

Yagi T, Matsuda J, Tominaga K, Suzuki K, Suzuki K (2005) Hematopoietic cell transplantation ameliorates clinical phenotype and progression of the CNS pathology in the mouse model of late onset Krabbe disease. J Neuropathol Exp Neurol 64:565-575. CrossRef Medline

Zaka M, Rafi MA, Rao HZ, Luzi P, Wenger DA (2005) Insulin-like growth factor-1 provides protection against psychosine-induced apoptosis in cultured mouse oligodendrocyte progenitor cells using primarily the PI3K/ Akt pathway. Mol Cell Neurosci 30:398-407. CrossRef Medline 